\title{
Essential oil composition and variability of Hypericum perforatum L. from wild population in Kosovo
}

\author{
Avni Hajdari ${ }^{1 *}$, Behxhet Mustafa ${ }^{1}$, Dashnor Nebija ${ }^{2}$, Albana Kashtanjeva ${ }^{1}$, \\ Jaroslaw Widelski ${ }^{3}$, Kazimierz Glowniak ${ }^{3}$, Johannes NovaK ${ }^{4}$ \\ ${ }^{1}$ Department of Biology, Faculty of Mathematical and Natural Science, University of Prishtina "Hasan Prishtina", \\ Mother Theresa 10000 Prishtinë, Kosovo \\ 2 Department of Pharmacy, Faculty of Medicine, University of Prishtina “Hasan Prishtina”, Bulevardi i Dëshmorëve, 10000 Prishtinë, \\ Kosovo \\ ${ }^{3}$ Department of Pharmacogosy with Medicinal Plants Laboartory, Medical Univeristy of Lublin Chodzki 1, 20-093 Lublin, Poland \\ ${ }^{4}$ Institute of Animal Nutrition and Functional Plant Compounds, University of Veterinary Medicine, Veterinärplatz 1, 1210 Vienna, \\ Austria
}

\begin{tabular}{l} 
ARTICLE INFO \\
\hline Received 14 February 2014 \\
Accepted 24 March 2014
\end{tabular}

Keywords:

essential oil,

Hypericum perforatum,

Kosovo,

natural variability.

\begin{abstract}
Aerial parts of Hypericum perforatum L. (Hypericaceae) were collected from five wild populations in Kosovo, with aim to investigate the chemical composition and natural variation of essential oils between wild populations. This species could be considered of economic potential as it is widespread in Kosovo, on the other hand $H$. perforatum is one of the best-known medicinal herbs used in Kosovo folk medicine. Essential oils were obtained by steam distillation and analysed by GC-FID and GC-MS. Sixty-seven components were identified. The yields of essential oils differed depending on the population and ranged from 0.04 to $0.26 \%$ based on dry weight. The aerial parts of $H$. perforatum were characterized by the following main constituents: 2-methyl-octane (1.1-15.5\%), $\alpha$-pinene (3.7-36.5\%), $\beta$-caryophyllene (1.2-12.4\%), caryophyllene oxide (3.3-17.7\%) and n-tetradecanol (3.6$10.4 \%)$. Hierarchical cluster analysis revealed that the concentration of components depends on the origin of the plant populations, thus $\alpha$-pinene and 2-methyl-octane were present in the highest concentration in population originating from Gjakovë, Prizren and Ferizaj, whereas in the populations originating from Pejë and Prishtinë the most abundant constituents were caryophyllene oxide, $\beta$-caryophyllene and n-tetradecanol. Further investigation is needed to establish the natural variability and chemopolymorphism of this species in the territory of Kosovo, which should be supported by molecular level analyses.
\end{abstract}

\section{INTRODUCTION}

The genus Hypericum L. belongs to the Hypericaceae family, which consists of 484 species at the most recent count and is present in every continent in the world, except the Antarctic [5]. Hypericum perforatum L. (common St. John's wort) is native to Europe, Asia, Africa, and is naturalized in Africa, Australia and the Americas [8]. This species is widespread in Kosovo and usually grows wild in habitats such as pastures, uncultivated lands, roadsides, woodlands, field edges, waste grounds, etc.

\footnotetext{
Corresponding author

* e-mail: avni.hajdari@uni-pr.edu

tel.: +38138249872

fax: +38138226104
}

It is a perennial herbaceous aromatic plant characterized by an erect, cylindrical, $10-100 \mathrm{~cm}$ tall stem, branched in the upper part. It has opposite, sessile, narrow ovate to linear leaves, with transparent dots throughout the tissue. Flowers are organized in board cymes at the end of the upper branches, with a yellow colour [16, 11]. Blooming occurs from May to August.

H. perforatum $\mathrm{L}$. has been used as a medicinal plant and it is one of the best-known members of the genus Hypericum L. as medicinal herb [5]. In Kosovo, it is one of the most frequently used herbs in folk medicine, used for different medicinal purposes like relief of temporary mental exhaustion, relief of mild gastrointestinal discomfort, topical preparations are used for the treatment of skin inflammations, sunburn and as an aid in healing minor wounds and ulcers, rheumatism, etc. [11, 12]. Although this species has been 
frequently used in folk medicine for different purposes, to the best of our knowledge no information on the chemical composition of this plant is available from Kosovo.

Apart from its use in the folk medicine, it is used in modern medicine as well. Due to its importance in the treatment of the moderate depression and its topical application, it has been recognized and approved as medicinal herb by the World Health Organization [9], European Pharmacopeia [7], etc.

$H$. perforatum L. is characterized with a diversity of bioactive constituents, which include naphtodianthrones (pseudohypericin, hypericin), phloroglucinol derivates (mainly hyperforin and adhyperforin ), flavonoids, catechin tannins, procyanidines, but this specie is known as a plant with poor content of essential oil $[3,13,18]$.

Recently, several investigations of the chemical composition of $H$. perforatum L. have been reported, including the chemical composition of essential oils originating from different regions such as Serbia $[10,15]$, Turkey $[4,6]$, Bulgaria [17], France [14], etc. Results obtained from previous investigations on essential oil composition of $H$. perforatum L. did not give homogeneous results [6, 10, 15]. These investigations documented that the variability of the chemical composition depended on genetic and environmental factors, ontogeny, season, plant part analyzed and analytical methods [15].

The aims of this study were to analyse the chemical composition of the essential oil and its natural variation between populations.

\section{MATERIAL AND METHODS}

\section{Plant material}

Plant material (aerial parts) of $H$. perforatum L. was collected during full flowering time (June-August 2012) from five different wild populations in Kosovo. The essential oil composition of 15 accessions was examined ( 3 accessions for each population). Voucher specimens of each population were deposited in the Herbarium of the Department of Biology, University of Prishtina (Table 1). Plant material was air-dried in shade at room temperature.

Table 1. Basic characterization of the sites from where the plant materials of $H$. perforatum populations were collected

\begin{tabular}{|c|c|c|c|c|c|}
\hline No. & Locality & Latitude & Longitude & Altitude $(\mathrm{m})$ & Voucher no. \\
\hline 1 & Ferizaj & $42^{\circ} 22^{\prime} 05^{\prime \prime} \mathrm{N}$ & $21^{\circ} 04^{\prime} 53.00^{\prime \prime} \mathrm{E}$ & $634 \mathrm{~m}$ & $04 / \mathrm{EO} / 11$ \\
\hline 2 & Prishtinë & $42^{\circ} 38^{\prime} 11^{\prime \prime} \mathrm{N}$ & $21^{\circ} 08^{\prime} 53.27^{\prime \prime} \mathrm{E}$ & $628 \mathrm{~m}$ & $01 / \mathrm{EO} / 11$ \\
\hline 3 & Pejë & $42^{\circ} 39^{\prime} 54^{\prime \prime} \mathrm{N}$ & $20^{\circ} 13^{\prime} 48.21^{\prime \prime} \mathrm{E}$ & $651 \mathrm{~m}$ & O2/EO/11 \\
\hline 4 & Gjakovë & $42^{\circ} 21^{\prime} 23^{\prime \prime} \mathrm{N}$ & $20^{\prime} 54.62^{\prime \prime} \mathrm{E}$ & $238 \mathrm{~m}$ & $05 / \mathrm{EO} / 11$ \\
\hline 5 & Prizren & $42^{\circ} 15^{\prime} 43^{\prime \prime} \mathrm{N}$ & $20^{\circ} 40^{\prime} 57.76^{\prime \prime} \mathrm{E}$ & $322 \mathrm{~m}$ & $03 / \mathrm{EO} / 11$ \\
\hline
\end{tabular}

\section{Isolation of essential oils}

Aerial parts of St John's Wort ( $50 \mathrm{~g}$ ) were cut into small pieces, and essential oils were obtained by hydro distillation in $500 \mathrm{ml}\left(\mathrm{H}_{2} \mathrm{O}\right)$ using a Clevenger apparatus for $3 \mathrm{~h}$. The samples were stored at $-18^{\circ} \mathrm{C}$ in the freezer until further analyses.

\section{GC and GC-MS analyses.}

GC/FID analyses were carried out using an Agilent 7890A GC System equipped with FID detector (Agilent
Technologies). The separation was performed on a HP-5MS column $30 \mathrm{~m} \times 0.25 \mathrm{~mm}$ with $0.25 \mu \mathrm{m}$ film thickness. Helium was used as carrier gas with an initial flow of 0.6 $\mathrm{ml} / \mathrm{min}$ and subsequently a constant pressure of $50.0 \mathrm{psi}$. The front inlet was maintained at $250^{\circ} \mathrm{C}$ at a split ratio of 50:1. The initial GC oven temperature was $60^{\circ} \mathrm{C}$ and it was increased to $260^{\circ} \mathrm{C}$ with $5^{\circ} \mathrm{C} / \mathrm{min}$, whereas FID operated at $250^{\circ} \mathrm{C}$ with an air flow of $350 \mathrm{ml} / \mathrm{min}$ and a hydrogen flow of $35 \mathrm{ml} / \mathrm{min}$. The injection volume was $1.0 \mu \mathrm{L}$.

GC/MS analyses were carried out using an Agilent 7890A GC System coupled with a 5975C MSD. The ionisation energy was $70 \mathrm{eV}$ with a mass range of $40-400 \mathrm{~m} / \mathrm{z}$. The separation was performed with the same column and temperature program as for the analytical GC.

Identification of the each components of the essential oil was made by comparing their Kovats retention indexes with those in literature [1]. Calculation of the Kovats index was made based on linear interpolation of the retention time of the homologous series of n-alkanes (C9-C20) under the same operating conditions. Also, identification of the components was made by comparing mass spectra of each constituent with those stored in the Wiley/NIST 05.L database and with mass spectra from the literature [1].

\section{Statistical analysis}

To determine the relationship among different accessions and population there was used a hierarchical cluster analysis using the percentage composition of all essential oils components (SPSS software computer package). The cluster analysis was constructed based on single linkage between the groups, employing the clustering method based on squared Euclidean distances.

\section{RESULTS}

The results on essential oil composition of the aerial parts of $H$. perforatum L. are reported in Table 2. Sixty-seven components were identified, the number of identified components differed, depending on populations (Table 2).

The hydrodistillation of the aerial parts of $H$. perforatum L. gave yellowish oils. The yields differed depending on the population origins and ranged from 0.04 to $0.26 \%$ based on dry weight (Table 2). The highest content of essential oils was found in the population from Gjakovë $(0.26 \% \mathrm{w} / \mathrm{w})$, whereas the lowest content was found in Prishtinë (0.04\% $\mathrm{w} / \mathrm{w})$.

The aerial parts of $H$. perforatum L. were characterised by the main components 2-methyl octane (1.1-15.5\%), $\alpha$-pinene (3.7-36.5\%), $\beta$-caryophyllene (1.2-12.4\%), caryophyllene oxide (3.3-17.7\%) and n-tetradecanol (3.6-10.4\%). The concentration of components depends on the origin of the plants populations (Table 2), thus 2-methyl octane and $\alpha$-pinene were present in the highest concentration in the populations originating from Gjakovë, Prizrenë and Ferizaj, whereas populations originated from Pejë and Prishtinë were dominated by caryophyllene oxide and $\beta$-caryophyllene.

The isolated essential oils were complex mixtures of hydrocarbons, monoterpenes, sesquiterpenes and diterpenes. Their concentration varied depending on origin of plant population too. Thus, essential oil of $H$. perforatum 
L. in the population originated from Gjakovë, Prishtinë and Prizren, was dominated by monoterpenes ranging from 16.1 to $46.9 \%$. The oxygenated monoterpenes ranged from 1.2 to $2.3 \%$. The sesquiterpenes ranged from 14.1 to $33.4 \%$ and were higher in the essential oil from the populations from Ferizaj and Pejë, whereas oxygenated sesquiterpenes ranged from 10.7 to $34.2 \%$. Hydrocarbons represented 3.2 to $20.1 \%$ of the total oil, whereas oxygenated hydrocarbons ranged from 6.4 to $14.9 \%$. The diterpene fractions of the essential oil were present in low quantities diterpenes (0.02-0.3\%), oxygenated diterpenes (0.1-1.073\%) (Table 2).

Table 2. The percentage (\%) composition of essential oils from areal parts in $H$. perforatum from five different wild populations in Kosovo (percentage represent the average of 3 replicates).

\begin{tabular}{|c|c|c|c|c|c|c|c|}
\hline & $\mathrm{KI}^{\mathrm{a}}$ & Compound & Ferizaj & Prizren & Gjakovë & Prishtinë & Pejë \\
\hline 1 & 881 & 2-Methyl octane & 13.24 & 9.27 & 15.54 & 1.13 & 1.94 \\
\hline 2 & 899 & n-Nonane & 1.36 & 0.87 & 1.31 & 0.00 & 0.32 \\
\hline 3 & 926 & Tricyclene & 0.46 & 0.15 & 0.00 & 0.14 & 0.10 \\
\hline 4 & 939 & $\alpha$-Pinene & 14.7 & 22.34 & 36.52 & 3.68 & 3.95 \\
\hline 5 & 968 & 3-Methyl nonane & 0.88 & 0.71 & 0.93 & 0.17 & 0.32 \\
\hline 6 & 979 & $\beta$-Pinene & 3.81 & 3.66 & 4.28 & 0.91 & 0.95 \\
\hline 7 & 990 & $\beta$-Myrcene & 0.81 & 1.13 & 1.37 & 0.26 & 0.28 \\
\hline 8 & 1020 & o-Cymene & 0.46 & 0.22 & 0.31 & 0.24 & 0.17 \\
\hline 9 & 1029 & d-Limonene & 0.46 & 0.42 & 0.41 & 0.17 & 0.17 \\
\hline 10 & 1034 & 1-8-Cineole & 0.71 & 0.22 & 0.16 & 0.11 & 0.14 \\
\hline 11 & 1044 & cis- $\beta$-Ocimene & 2.70 & 1.65 & 0.90 & 0.54 & 0.83 \\
\hline 12 & 1063 & 2-Methyl decane & 0.99 & 1.76 & 1.44 & 0.82 & 0.96 \\
\hline 13 & 1099 & Undecane & 0.69 & 0.67 & 0.59 & 0.36 & 0.53 \\
\hline 14 & 1135 & trans-Pinocarveol & 0.24 & 0.10 & 0.10 & 0.12 & 0.12 \\
\hline 15 & 1142 & trans-Sabinol & 0.36 & 0.14 & 0.10 & 0.12 & 0.14 \\
\hline 16 & 1162 & Pinocarvone & 0.30 & 0.24 & 0.19 & 0.09 & 0.12 \\
\hline 17 & 1177 & Terpinene-4-ol & 0.44 & 0.82 & 0.48 & 0.69 & 0.73 \\
\hline 18 & 1188 & $\alpha$-Terpineol & 0.15 & 0.17 & 0.08 & 0.13 & 0.17 \\
\hline 19 & 1194 & Myrtenol & 0.00 & 0.00 & 0.12 & 0.30 & 0.38 \\
\hline 20 & 1204 & Verbenone & 0.00 & 0.19 & 0.00 & 0.19 & 0.00 \\
\hline 21 & 1263 & 2-Methyldodecane & 0.35 & 0.13 & 0.26 & 0.20 & 0.45 \\
\hline 22 & 1299 & Tridecane & 0.15 & 0.29 & 0.24 & 0.16 & 0.29 \\
\hline 23 & 1351 & $\alpha$-Cubene & 0.17 & 0.25 & 0.20 & 0.11 & 0.22 \\
\hline 24 & 1351 & $\alpha$-Longipinene & 0.16 & 0.2 & 0.14 & 0.19 & 0.15 \\
\hline 25 & 1375 & $\alpha$-Ylangene & 0.84 & 0.27 & 0.19 & 0.64 & 0.87 \\
\hline 26 & 1376 & $\alpha$-Copaene & 0.14 & 0.27 & 0.20 & 0.00 & 0.33 \\
\hline 27 & 1384 & $\beta$-Bourbonene & 0.21 & 0.05 & 0.03 & 0.00 & 0.00 \\
\hline 28 & 1390 & $\beta$-Elemene & 0.31 & 0.19 & 0.21 & 0.19 & 0.50 \\
\hline 29 & 1418 & $\beta$-Cedrene & 0.24 & 0.08 & 0.02 & 0.11 & 0.08 \\
\hline 30 & 1419 & $\beta$-Caryophyllene & 1.22 & 3.59 & 2.63 & 12.41 & 11.18 \\
\hline 31 & 1433 & $\beta$-Gurjenene & 0.00 & 0.26 & 0.20 & 0.13 & 0.32 \\
\hline 32 & 1439 & $\alpha$-Guaiene & 0.17 & 0.27 & 0.25 & 0.15 & 0.65 \\
\hline 33 & 1454 & Neryl propanoate & 2.36 & 3.34 & 1.18 & 1.68 & 2.7 \\
\hline 34 & 1454 & $\alpha$-Caryophyllene & 0.58 & 0.25 & 0.07 & 0.28 & 0.24 \\
\hline 35 & 1461 & \begin{tabular}{|l|} 
Allo- \\
aromadendrene
\end{tabular} & 0.19 & 0.13 & 0.10 & 0.13 & 0.25 \\
\hline 36 & 1475 & n-Dodecanol & 3.19 & 2.38 & 2.54 & 1.97 & 4.64 \\
\hline 37 & 1477 & Y-Muurolene & 1.03 & 1.64 & 1.09 & 1.15 & 0.00 \\
\hline 38 & 1482 & Germacrene D & 3.59 & 3.21 & 2.05 & 4.57 & 5.67 \\
\hline 39 & 1490 & $\begin{array}{l}\text { E-Muurola -4 (14), } \\
\text { 5-diene }\end{array}$ & 0.32 & 0.3 & 0.18 & 0.26 & 0.46 \\
\hline 40 & 1495 & $\gamma$-Amorphene & 0.38 & 0.51 & 0.32 & 0.34 & 0.62 \\
\hline 41 & 1500 & Bicyclogermacrene & 0.60 & 0.50 & 0.23 & 0.93 & 1.21 \\
\hline 42 & 1513 & $\gamma$-Cadinene & 0.53 & 0.87 & 0.60 & 0.71 & 1.08 \\
\hline 43 & 1524 & 8-Cadinene & 0.94 & 1.44 & 1.01 & 1.22 & 1.79 \\
\hline 44 & 1538 & $\alpha$-Cadinene & 0.46 & 0.23 & 0.16 & 0.25 & 0.29 \\
\hline 45 & 1548 & $\alpha$-Calacorene & 1.18 & 1.81 & 0.86 & 0.00 & 1.46 \\
\hline 46 & 1563 & Unknown & 0.21 & 0.00 & 0.00 & 0.54 & 0.00 \\
\hline
\end{tabular}

\begin{tabular}{|l|c|l|c|c|c|c|c|}
\hline 47 & 1564 & (E)-Nerolidol & 0.37 & 0.46 & 0.37 & 3.44 & 0.55 \\
\hline 48 & 1582 & Pygmaein & 2.91 & 2.36 & 1.77 & 1.78 & 3.43 \\
\hline 49 & 1578 & (-)-Spathulenol & 5.47 & 2.03 & 1.47 & 0.00 & 2.38 \\
\hline 50 & 1583 & Cariophyllene oxide & 7.34 & 6.59 & 3.63 & 17.71 & 11.87 \\
\hline 51 & 1590 & Globulol & 0.38 & 0.22 & 0.20 & 0.60 & 0.82 \\
\hline 52 & 1608 & Humulene epoxide II & 0.72 & 0.61 & 0.39 & 0.58 & 0.69 \\
\hline 53 & 1641 & $\begin{array}{l}\text { Caryophylla- } \\
4(14), 8(15) \text {-ien-5ol }\end{array}$ & 4.24 & 3.26 & 1.87 & 3.57 & 3.53 \\
\hline 54 & 1642 & Cubenol & 1.19 & 0.33 & 0.36 & 0.98 & 0.65 \\
\hline 55 & 1646 & $\alpha$-Muurolol & 0.00 & 0.52 & 0.30 & 0.35 & 0.49 \\
\hline 56 & 1656 & $\alpha$-Cadinol & 0.34 & 0.35 & 0.22 & 0.22 & 0.42 \\
\hline 57 & 1652 & y-Himachalene & 0.33 & 0.13 & 0.09 & 0.30 & 0.30 \\
\hline 58 & 1670 & $\begin{array}{l}\text { l4-Hydroxy-9-epi- } \\
\text { (E)-caryophyllene }\end{array}$ & 0.70 & 0.95 & 0.68 & 0.99 & 1.18 \\
\hline 59 & 1675 & n-Tetradecanol & 3.81 & 5.17 & 3.62 & 10.45 & 9.78 \\
\hline 60 & 1687 & $\begin{array}{l}\text { Eudesma-4(15), } \\
7-\text {-diene-1 } \beta \text {-ol }\end{array}$ & 0.66 & 0.79 & 0.40 & 0.58 & 0.77 \\
\hline 61 & 1774 & $\alpha$-Costol & 0.28 & 0.35 & 0.18 & 0.00 & 0.41 \\
\hline 62 & 1848 & Unknown & 0.32 & 0.54 & 0.23 & 0.00 & 0.34 \\
\hline 63 & 1881 & Cyclohexadecane & 0.05 & 0.42 & 0.22 & 0.31 & 0.34 \\
\hline 64 & 1899 & Nonadecane & 1.25 & 0.43 & 0.3 & 1.07 & 1.01 \\
\hline 65 & 1852 & $\begin{array}{l}\text { n-Pentadecanoic } \\
\text { acid }\end{array}$ & 0.30 & 0.15 & 0.11 & 0.14 & 0.24 \\
\hline 66 & 1942 & Phytol & 0.84 & 0.32 & 0.14 & 0.52 & 0.86 \\
\hline 67 & 2000 & Eicosane & 0.10 & 0.22 & 0.02 & 0.23 & 0.28 \\
\hline & & $\begin{array}{l}\text { Yield (\% w per dry } \\
\text { weight) }\end{array}$ & 0.12 & 0.13 & 0.26 & 0.04 & 0.06 \\
\hline & & Total & 92.66 & 93.41 & 96.37 & 82.29 & 88.13 \\
\hline & & Monoterpene \% & 27.61 & 33.33 & 46.95 & 16.10 & 17.22 \\
\hline & & $\begin{array}{l}\text { Oxygenated } \\
\text { monoterpenes\% }\end{array}$ & 2.37 & 2.01 & 1.28 & 2.13 & 2.04 \\
\hline & & Sesquiterpene \% & 16.19 & 21.21 & 14.10 & 29.26 & 33.42 \\
\hline & & $\begin{array}{l}\text { Oxygenated } \\
\text { sesquiterpenes \% }\end{array}$ & 24.25 & 18.71 & 10.75 & 34.22 & 27.56 \\
\hline & & Diterpene \% & 0.11 & 0.24 & 0.02 & 0.28 & 0.32 \\
\hline & & $\begin{array}{l}\text { Oxygenated } \\
\text { Diterpene \% }\end{array}$ & 0.91 & 0.34 & 0.15 & 0.63 & 0.98 \\
\hline & & Hydrocarbons \% & 18.11 & 13.91 & 20.11 & 3.24 & 5.10 \\
\hline $\begin{array}{l}\text { Oxygenated } \\
\text { hydrocarbons\% }\end{array}$ & 9.89 & 9.67 & 6.40 & 14.48 & 12.99 \\
\hline Others \% & 0.58 & 0.24 & 0.66 & 0.39 \\
\hline
\end{tabular}

${ }^{a}$ Kovats Index calculated against C9-C40 n-alkanes mixture on the HP 5MS column. ctr - Trace $(<0.1 \%)$

To identify possible relationships between volatile compounds and geographical locations, the hierarchical cluster analysis was employed. All identified components of the examined accessions of $H$. perforatum L., were used for statistical analyses. The dendrogram generated from the single linkage between the groups, employing the clustering method based on squared Euclidean distances performed on the essential oils compounds of $H$. perforatum L. populations showed the existence of two main clusters (Fig. 1). The two main clusters are separating the populations from Prizren, Ferizaj and Gjakovë (group 1) and Pejë and Prishtinë (group 2) as differentiated before into chemotypes, demonstrating - as could be expected - the big differences of the major compounds used to define the chemotypes exerting the highest influence in the cluster analysis. 


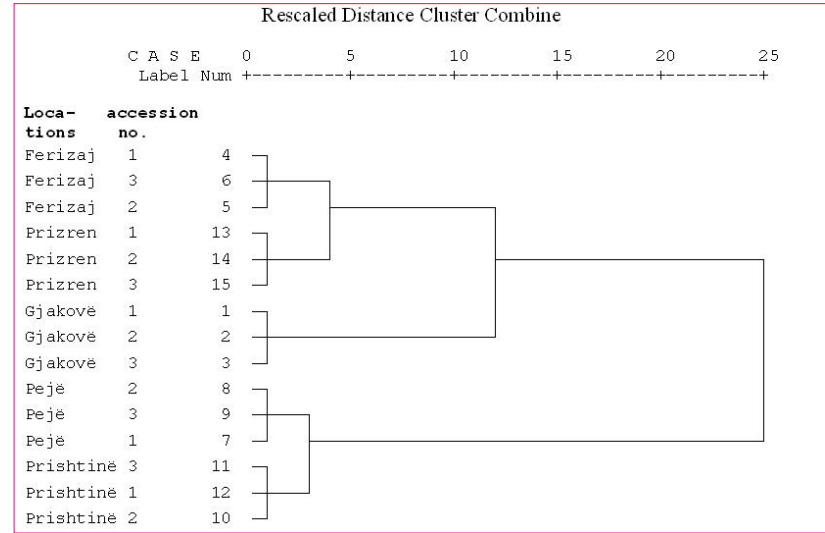

Figure 1. Dendrogram obtained by cluster analysis based on Euclidean distance performed on the essential oil compounds of the $H$. perforatum originated from five populations

\section{DISCUSSION}

The yields of essential oils differed depending on the population origins and in our population ranged from 0.04 to $0.26 \%$ based on dry weight. Previous studies show that yield of $H$. perforatum oils varies depending on the origin of plant material and ranging from $0.02 \%$ to $2.2 \% \mathrm{w} / \mathrm{w}[10,15$, $4,2]$. Accordingly the contents of essential oils originating from Serbia were 0.03-1.93 [10], France 0.03-0.12\% [14] and Turkey, $0.04-0.5 \%$ [4].

The composition of the essential oil of Hypericum perforatum L. originating from five different regions in Kosovo did not show uniformity in chemical composition. Thus, the results show that two chemotypes could be distinguished from the analysed populations, taking into consideration that essential oil chemotypes are determined on the basis of major compounds. The first group represented by the populations Prizren, Ferizaj and Gjakovë, is characterized by oils rich in 2-methyl octane and $\alpha$-pinene and second chemotype originating from Pejë and Prishtinë is characterized by the presence of caryphyllene oxide and $\beta$-caryophyllene as major compounds. 2 methyloctane and $\alpha$-pinene as main components of $H$. perforatum L. oil were reported in population originating from different regions [15, 4], whereas caryphyllene oxide and $\beta$-caryophyllene as main components were the main constituents of the oil of $H$. Perforatum L. from Uzbekistan [2] and epi-bicyclosesquiphellandrene and $n$-alkanes from the oil of $H$. perforatum L. from Bulgaria [17]. Further investigation is needed to establish the natural variability and chemopolymorphism of this species in the territory of Kosovo, which should be supported by molecular level analyses.

\section{ACKNOWLEDGEMENT}

The authors wish to thank the Ministry of Education and Science and Technology, Republic of Kosovo for providing funding for the completion of this work.

\section{REFERENCES}

1. Adams RP. (2009). Identification of Essential Oil Components by Gas Chromatography/Mass Spectrometry. $4^{\text {th }}$ Edn., Allured Publishers, Carol Stream, IL., USA.

2. Baser K.H.C., Ozek T., Nuriddinov H.R., Demirci A.B.: Essential oil of two Hypericum species from Uzbekistan. Chem. Nat. Compd., 38:1, 54-57, 2002.

3. Bradley, P. British Herbal Compendium. Vol 2. British Herbal Medicin Association, 2006.

4. Cakir A., Duru M.E., Harmandar M., Ciriminna R., Passannanti S., Piozzi F., Comparison of the volatile oils of Hypericum scabrum L. and Hypericum perforatumin Turkey. Flavour Fragrance J., 12, 285-287, 1997.

5. Crockett S.L., Robson N.K.: Taxonomy and chemotaxonomy of the genus Hypericum Med. Aromat. Plant Sci. Biotechnol., 5, 1-13, 2011.

6. Erken S., Malyer H., Demirci F., Demirci B., Baser K.H.C., Chemical investigations on some Hypericumspecies growing in Turkey-I. Chem. Nat. Compd., 37, 434-438, 2002.

7. European Pharmacopeia. (2011). European Pharmacopoeia. $6^{\text {th }}$ Edn., Maisonneuve Publishers, Strasbourg, France.

8. Hobbs C.: St. John's wort, Hypericum perforatum L. Herbalgram, 18, 24-33, 1989.

9. Mahady G.B., Fong H.H.S., Farnsworth N.R. (2001). WHO monographs of selected medicinal plants II. World Health Organization, Geneva, Switzerland.

10. Mimica-Dukic N., Ivancev-Tumbas I., Igic R., Popovic M., Gasic O.: The content and composition of essential oil of Hypericum perforatumfrom Serbia. Pharm. Pharmacol. Lett., 8, 26-28, 1997.

11. Mustafa B., Hajdari A., Krasniqi F., Hoxha E., Ademi H., Quave C.L., Pieroni A., Medical ethnobotany of the Albanian Alps in Kosovo. J. Ethnobiol. Ethnomed., 8:6, 1-14, 2012.

12. Mustafa B., Hajdari A., Pajazita Q., Syla B., Quave C.L., Pieroni A., An ethnobotanical survey of the Gollak region, Kosovo. Gen. Resour. Crop Evol., 59, 739-754, 2012.

13. Nahrstedt A, Butterweck V. Biologically active and other chemical constituents of the herb of Hypericum perforatum L. Pharmacopsychiatry, 30, 129-134, 1997.

14. Schwob I., Bessiere J.M., Viano, J. Composition of the essential oils of Hypericum perforatum L. from Southeastern France. C.R. Biologies, 325, 781-785, 2002.

15. Smelcerovic A., Spiteller M., Ligon A.P., Smelcerovic Z., Raabe N.: Essential oil composition of Hypericum L. species from Southeastern Serbia and their chemotaxonomy. Biochem. Syst. Ecol., 35, 99-113, 2007.

16. Tutin G.T., Haywood H.V., Burges A.N., Moore D.M., Valentine D.H., Walters S.M., Webb D.A. (1972) Flora Europea. Vol. 3, Cambridge University Press, Cambridge, UK.

17. Vasileva R., Georgieva V., Vojnova J., Milkova T.: GC-MS study on the essential oils of Bulgarian Hypericum maculatum Grantz and Hypericum perforatum L. Comptes Rendus Academie Bulgare Sciences, 56, 71-74, 2003.

18. Wichtl, M. Teedrogen. Wissenschaftliche Verlagsgesellschaft $\mathrm{mbH}$, Stuttgart, 4. Auflage 2002. 